\title{
531 超音波センサによる油の劣化判定 \\ Estimation of Degraded Oil by Ultrasonic Sensor
}

\section{○正 高橋 義雄（秋田県立大学）＼cjkstart正 佐々木 芳宏（秋田大学）}

\section{Yoshio TAKAHASHI, Akita Prefectural University, 84-4 Tuchiya, Honjo City, Akita}

Yoshihiro SASAKI, Akita University, 1-1 Tegata Gakuencho, Akita City, Akita

\begin{abstract}
One of the most important problems in an oil hydraulic system is the contamination problem. The aim of this study is to evaluate numerically the contamination of an oil. The measurement is carried out to evaluate a degraded oil using the ultrasonic sensor. As the ultrasonic wave propagates through a degraded oil, the energy of the ultrasound is scattered by the contaminant particle, and hence the some attenuation is occurred. This indicated that the attenuation of ultrasonic wave is closely connected with the distribution of each contamination particles.
\end{abstract}

Key Words: Oil, Contamination, Degraded Estimation, Ultrasonic Sensor, Attenuation

超音波は電磁波に比べて伝搬速度が非常に遅く，かつ波 長が短いため距離方向の分解能が高いため高精度の計測が 期待できる.

本研究は, 超音波センサを用いて油の劣化評価を実験的 に試みたものである。供試油は，NAS 等級や使用箇所が異 なる 8 種類の油で, その分析結果の一例を Table A1 に示す.

Fig. A1 に示す実験装置は，油の循環部，温度制御部およ び測定部から構成されている．超音波センサの周波数は 5 $\mathrm{MHz}$ で，方式は一探触子法である. 超音波の速度は伝搬媒 体中の温度に依存するため，油温分布を均一にするように 十分に攪汼した．超音波トランスデューサから出力される 超音波アナログ反射信号を, A/D 変換器を介してパーソナ ルコンピュータに取り込み，その時の超音波エコーの振幅 值を計測する．超音波の減衰を油の劣化評価基準とするた め, 次式を用いて減衰係数 $\alpha(\mathrm{dB} / \mathrm{cm})$ を求めた.

$$
\alpha=20 \times \log _{10}\left(A_{0} / A_{x}\right) \times 10^{4} /(2 \times \Delta x) \quad \cdots \cdots \cdot(\mathrm{A} 1)
$$
ただし，

$\Delta x$ : 基準となる反射板位置からの伝搬距離

$$
\left(\Delta x=L-l_{0}\right)
$$

$A_{0}$ : 超音波の伝搬距離が $2 l_{0}$ の時の振幅值

$A_{x}$ : 超音波の伝搬距離が $2 L$ の時の振幅値

Fig. A2 は油温を $32^{\circ} \mathrm{C}$ 一定とした場合の減衰係数と NAS 等級との関係を示した一例である.NAS 等級が大きくなる ほど減衰係数は高い值を示している．従来から油の劣化判

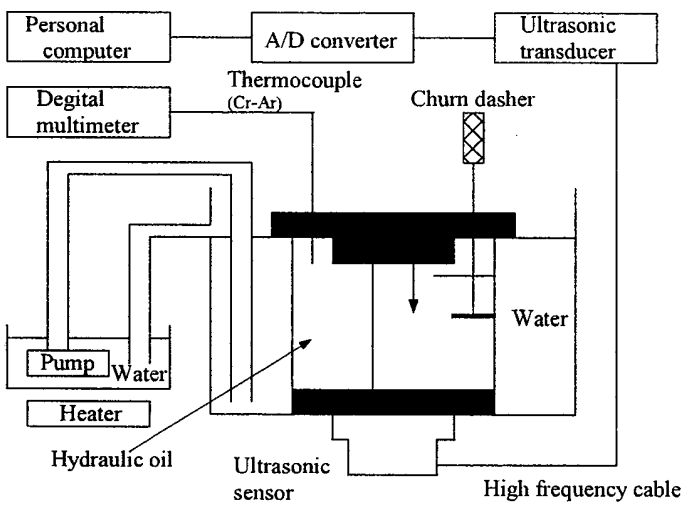

Fig. A1 Schematic diagram of experimental apparatus
定に用いられているNAS 等級の評価より, 本結果は, より 細かな等級分けが可能であることを示唆しているものと考 えられる，すなわち，これまで一般に用いられてきた NAS 等級よりも,より定量的に，かつリアルタイムで油の劣化 判定が可能であることを示した。

Table A1 Size distribution of contaminate particles in group B oils

\begin{tabular}{|l|r|r|r|r|r|r|}
\hline & No.4 & No.5 & No.6 & No.7 & No.8 \\
\hline Diameter & \multicolumn{5}{|c|}{ Particle Number/100ml } \\
\hline $5 \sim 15(\mu \mathrm{m})$ & 2420 & 15600 & 56050 & 439990 & 512820 \\
\hline $15 \sim 25(\mu \mathrm{m})$ & 490 & 1090 & 3560 & 35400 & 326650 \\
\hline $25 \sim 50(\mu \mathrm{m})$ & 70 & 630 & 690 & 11390 & 466380 \\
\hline $50 \sim 100(\mu \mathrm{m})$ & 20 & 170 & 190 & 680 & 58630 \\
\hline Over 100 $(\mu \mathrm{m})$ & 0 & 20 & 40 & 20 & 1470 \\
\hline NAS grade & 4 & 7 & 8 & 11 & 12 \\
\hline
\end{tabular}

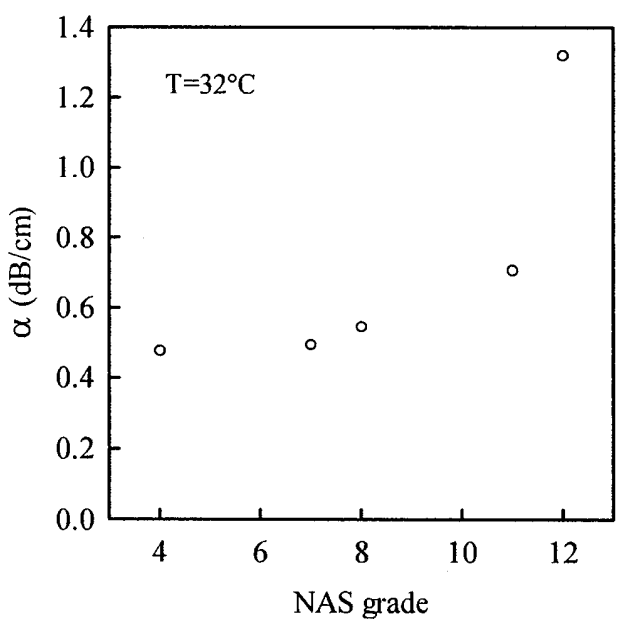

Fig. A2 Relation between NAS grade and damping coefficient of group B 


\section{1. 緒言}

超音波センサは，ロボットの動きに障害となる物体の検 知センサとして用いられているほか, 各種分野で数多く利 用されている，超音波の速度は伝搬媒体中の温度に依存す るため誤差を生じるが，電磁波など他の搬送波に比べて伝 搬速度が非常に遅く，かつ波長が短いため距離方向の分解 能が高く，高精度の計測が期待できる．一般に音波が伝搬 しながら強度が減少する要因として次の 3 つが考えられて いる(1).

(1) 音波が幾何学的に広がることによる拡散减衰

(2) 音波のパワーが媒質に吸収されて熱に変換されるこ とによる吸収減衰

（3）伝搬媒体中の不均質による散乱減衰がある.

伝搬する音波が $x$ 方向に伝搬する平面波ならば吸収と散 乱による減衰が観測される。

一般の油圧制御システムの作動油中に混入する污染物 としては, 金属粉, 溶接のスケール, 鉄錆び, ちりほこり, 剥離した塗料，およびパッキン材の切片等があげられる. これらの污染物は肉眼では見えない程度の大きさであるが， 制御機器の潤滑, その動作に悪影響をおよぼす。したがっ て, 作動油中の污染物の混入状態をリアルタイムで把握す ることは, システムの保守管理面から, さらにはその信頼 性を向上させなければならないことからも是非必要であり， 重要な研究課題であると考えられる. 本研究では, 今まで の NAS 等級のような主に目視判定に委礼られてきた作動 油の劣化判定を, 安価で入手しやすく, かつ各種制御のフ ィードバックセンサとして使用できる超音波センサを用い て, 油の劣化判定の可能性を実験的に検討考察したので報 告する.

\section{2. 実験装置および測定方法}

\section{$2 \cdot 1$ 供試油}

供試油のサンプルとして，A， B 二つのグループを採用 した.

A グループには，一般鉣油の新油（以下 No.1 と記す），1 年程度使用した油 (以下 No. 2 と記す)，および 2 年程度使 用した油（以下No.3 と記す）の 3 種類が含まれる. 新油の 粘度は ISO 等級のV VG-46である.この供試油の污染粒子数 を粒子カウンターで測定した結果を Table 1 に示す. NAS 等級は, Table $2^{(2)}$ に示すように，一般に作動油の劣化を判 定するために用いられている指標である。すなわち，等級 には $00 \sim 12$ のクラスが存在し, 各粒子径別のカウント数で もってそのクラスが決定される.この場合, 等級の数值が 大きい程油の劣化が進行していると判断される．A グルい プの供試油中に混入している污染粒子は鉄系のものが多い. ここで, NAS 等級が同一の 2 種類の油では, No.2にはサイ ズの小さいものが比較的多く, No.3には逆に大きいサイズ の粒子が目立っている.

$\mathrm{B}$ グループは, NAS 等級や使用箘所が異なる 5 種類の油 が含まれており，その分析結果を Table 3 に示す. NAS 等 級の小さい值から，それぞれNo.4〜8 でも, No.8 の油は極端に污れていることが分かる.

\section{$2 \cdot 2$ 実験装置}

Fig.1 は本研究で用いた実験装置である。実験装置は, シ リンダ，ポンプを含めた油の循環部，恒温槽，熱電対を含 む温度制御部, および超音波探触子, 超音波トランスデュ 一サ，マイクロメータ，パーソナルコンピュータの測定部 の主に 3 つの要素から構成されている. 油循環部のシリン ダは, 内径 $30 \mathrm{~mm}$, 高さ $120 \mathrm{~mm}$ とし, 特に反射板の探触子

Table 3 Size distribution of contaminate particles in group B oils

\begin{tabular}{|l|r|r|r|r|r|}
\hline & No.4 & No.5 & No.6 & No.7 & No.8 \\
\hline Diameter & \multicolumn{5}{|c|}{ Particle Number/100ml } \\
\hline $5 \sim 15(\mu \mathrm{m})$ & 2420 & 15600 & 56050 & 439990 & 512820 \\
\hline $15 \sim 25(\mu \mathrm{m})$ & 490 & 1090 & 3560 & 35400 & 326650 \\
\hline $25 \sim 50(\mu \mathrm{m})$ & 70 & 630 & 690 & 11390 & 466380 \\
\hline $50 \sim 100(\mu \mathrm{m})$ & 20 & 170 & 190 & 680 & 58630 \\
\hline Over 100 $(\mu \mathrm{m})$ & 0 & 20 & 40 & 20 & 1470 \\
\hline NAS grade & 4 & 7 & 8 & 11 & 12 \\
\hline
\end{tabular}

Table 2 NAS Grade

\begin{tabular}{|c|c|c|c|c|c|c|c|c|c|c|c|c|c|c|}
\hline & \multicolumn{14}{|c|}{ Grade (Particle Number $/ 100 \mathrm{ml}$ ) } \\
\hline Diameter & 00 & 0 & 1 & 2 & 3 & 4 & 5 & 6 & 7 & 8 & 9 & 10 & 11 & 12 \\
\hline $5-15(\mu \mathrm{m})$ & 125 & 250 & 500 & 1000 & 2000 & 4000 & 8000 & 16000 & 32000 & 64000 & 128000 & 256000 & 512000 & 1024000 \\
\hline $15-25(\mu \mathrm{m})$ & 22 & 44 & 88 & 178 & 356 & 712 & 1425 & 2850 & 5700 & 11400 & 22800 & 45000 & 91000 & 182000 \\
\hline $25-50(\mu \mathrm{m})$ & 4 & 8 & 16 & 32 & 63 & 126 & 253 & 506 & 1012 & 2025 & 4050 & 8100 & 16200 & 32400 \\
\hline $50-100(\mu \mathrm{m})$ & I & 2 & 3 & 6 & 11 & 22 & 45 & 90 & 180 & 360 & 720 & 1440 & 2880 & 57600 \\
\hline Over $100(\mu \mathrm{m})$ & 0 & 0 & 1 & 1 & 2 & 4 & 8 & 16 & 32 & 64 & 128 & 256 & 512 & 1024 \\
\hline
\end{tabular}




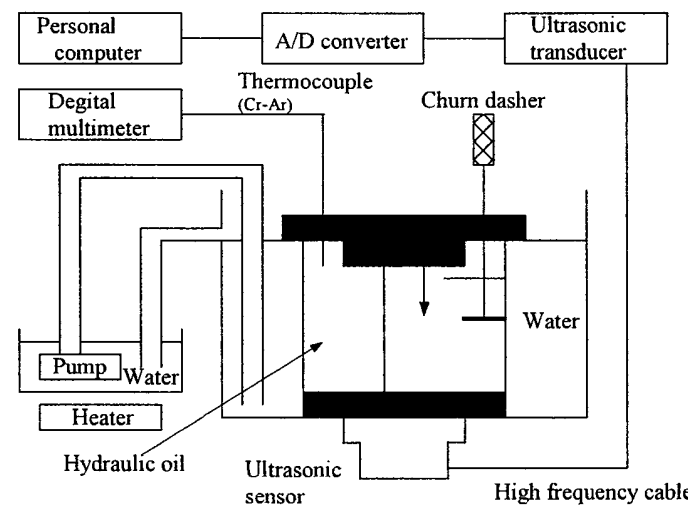

Fig. 1 Schematic diagram of experimental apparatus

側と底板との両面は超音波の反射損失を低く抑えるため十 分にその表面を仕上げた．また，測定中の時間経過に伴う 油の状態変化および油温変化をさけるためシリンダの外側 の水槽を温水で満たし，それをポンプで循環させることに よりシリンダ内の油温を制御している。 さらに，油温分布

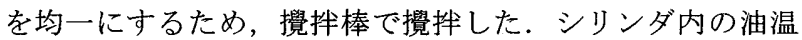
は, 循環回路中に恒温槽を用いて制御し, クロメル・アル メル熱電対で測定した。超音波探触子および超音波トラン スデューサは何れも帝通電子研究所製で，その仕様は次の 通りである。

超音波探触子：広帯域形垂直探触子 4502

方式: 一探触子法, 直接接触子法

振動子材質 : 圧電磁器発振, 周波数 : $5 \mathrm{MHz}$

振動子の公称寸法 : 直径 $26 \mathrm{~mm}$

超音波トランスデューサ：超音波探触子 UFD-360

パルス繰り返し周波数：1000,500,250,125,62.5Hz

一般に物性に関する研究においては，測定によってその手 法に相違はあるが, パルス法では数 $\mathrm{MHz}$ 域の発振周波数 を持つ超音波探触子での測定が最も容易で，かつ高い精度 の測定が得られるといわれている(3). したがって，本研究 では上記仕様の超音波挆触子を選定した。

\section{$2 \cdot 3$ 測定方法}

超音波トランスデューサから出力される超音波アナログ 反射信号を, $\mathrm{A} / \mathrm{D}$ 変換器を介してパーソナルコンピュータ に取り込み，その時の超音波エコーの振幅值を計測する. 超音波の減衰を油の劣化評価基準とするため, 次式を用い て減衰係数 $\alpha(\mathrm{dB} / \mathrm{cm})$ 求めた.

$$
\alpha=20 \times \log _{10}\left(A_{0} / A_{x}\right) \times 10^{4} /(2 \times \Delta x)
$$
ただし,

$\Delta x$ : 基準となる反射板位置からの伝搬距離

$$
\left(\Delta x=L-l_{0}\right)
$$

$A_{0}$ : 超音波の伝搬距離が $2 l_{0}$ の時の振幅值

$A_{x}$ : 超音波の伝搬距離が $2 L$ の時の振幅值

測定における超音波波形のモデルを Fig.2に示す.ここで, $\Delta x$ は 3,6,9,12,15mm の 5 段階としてそれぞれの場合の $A_{x}$ と $A_{0}$ を測定し, 上式に代入して減衰係数を算出した. また, 油温 $T$ は約 $20 \sim 60^{\circ} \mathrm{C}$ の間に設定した.

また, 油温 $T$ における音速 $v(\mathrm{~m} / \mathrm{s})$ は, 次の実験式で与え られる。

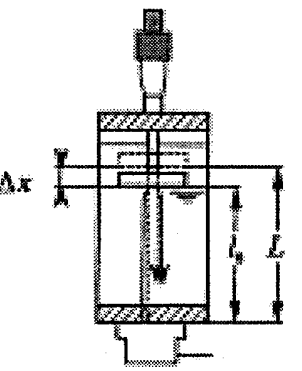

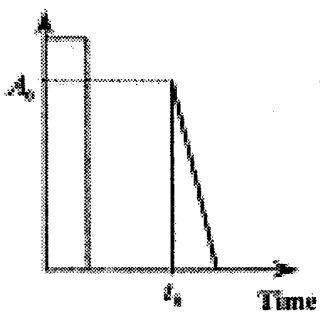

$\Delta x=0(\mathrm{mw})$

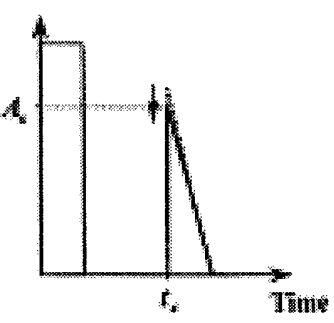

$4 x-3,6,9,2,15$ (mom)
Fig. 2 Model of ultrasonic wave

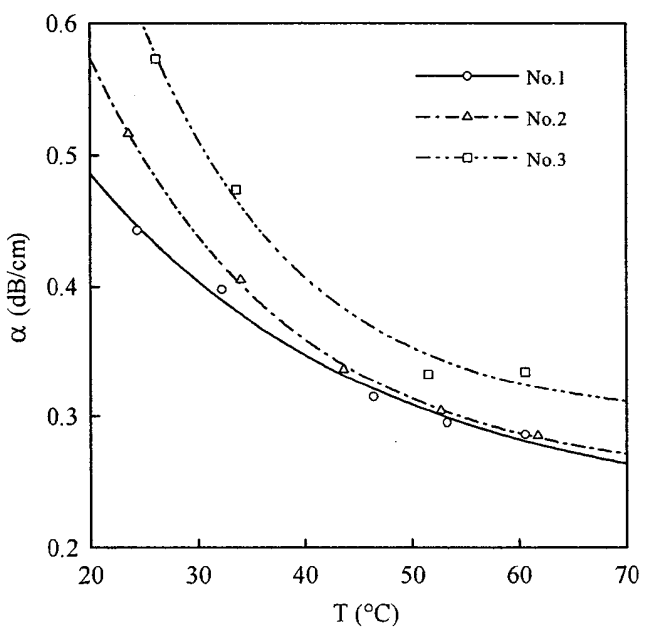

Fig. 3 Relation between oil temperature and damping coefficient of group A

$$
v=1534.8-4.0791 \times T+5.0044 \times 10^{-3} \times T^{2}
$$

\section{3. 結果および考察}

Fig.3 は, 一例として A グループの供試油（以後特に断 らない限りこの供試油の測定結果を示す）を用いて測定し た減衰係数におよぼす油温変化の影響を示したものである. 全測定温度範囲にわたり長期間使用した No.3 の減衰係数 の值は高いが，油温が高くなるにつれてその值が小さくな る傾向がある. また, 油温が低いほど減衰係数の差は大き くなり，40ㄷ上の油温からはその差がほとんどなくなっ てくる.このように, 減衰係数に差が生じた原因としては, 污染粒子の含有量の相違が考えられる. 超音波が粒子に衝 


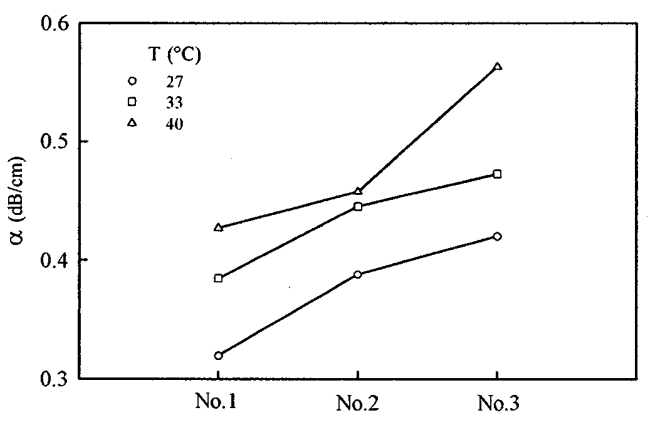

Fig. 4 Damping coefficient of group A

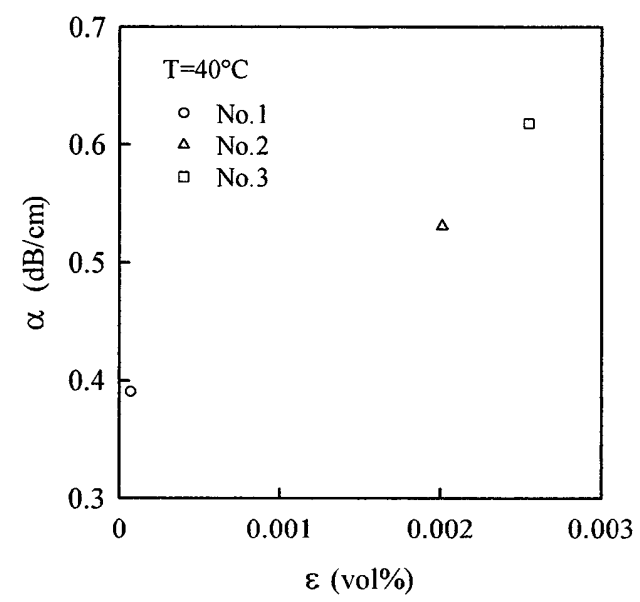

Fig. 5 Relation between volume ratio and damping coefficient of group A

突して散乱するため，污染粒子が最も多く含まれている No.3 の減衰がより大きくなり, 減衰係数の值が大きくなる と考えられる。一方, 油温が高いほど減衰係数が小さくな るのは, 減衰係数汇油の粘性に比例するため ${ }^{(4)}$, 油温上昇 による油の粘性が低下することに起因していると考えられ る。

Fig.4 は，3 種類の油を同一温度に設定して減衰係数を求 めたものである．何れの油温においても油の使用年数が多 いほど減衰係数は大きくなり，かつ油温が低いほどその值 が大きくなる傾向がある。この結果は, Fig.3で述べたと同 様の理由であると考えられる。

A グループ， B グループの油に対して，シリンダ体積に 占める污染粒子の割合，すなわち体積比を変化させた場合 の減衰係数の影響を示したのが Fig.5 および Fig.6 である. ただし，A グループにおける測定時の油温は $40^{\circ} \mathrm{C}$, B グル

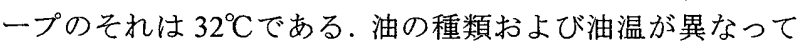
いても，体積比の増加とともに減衰係数は増大する傾向を 示している。これも前述したように，油中に含まれている 污染粒子の増加で吸収減衰, 散乱減衰が大きくなったため と考えられる.

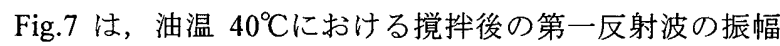
変化を示したものである。縦軸に擋汼直後の振幅を 1 とし た場合の振幅比を,横軸に擋找後の経過時間をとっている.

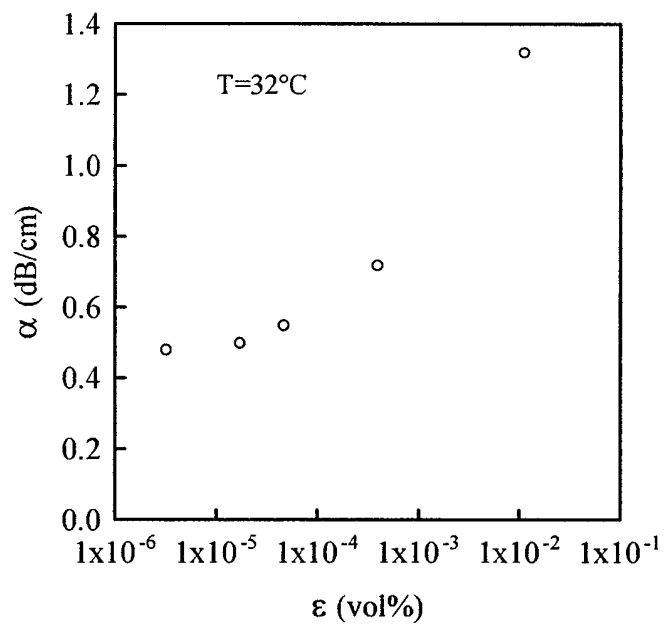

Fig. 6 Relation between volume ratio and damping coefficient of group A

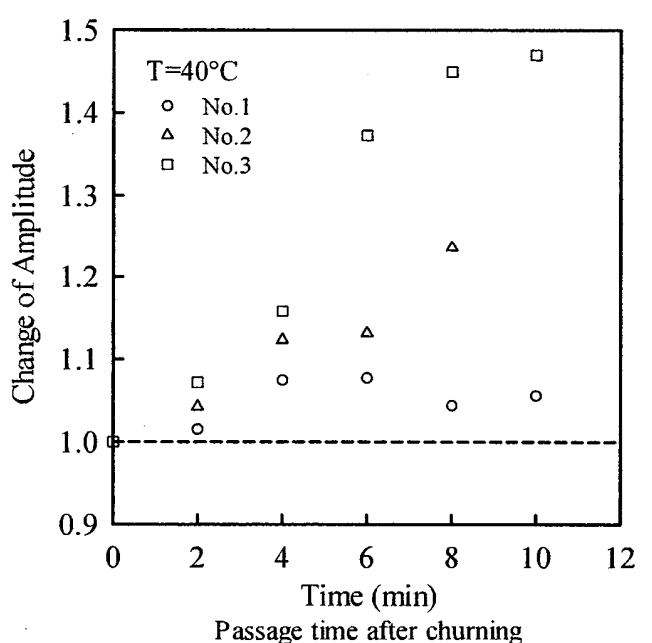

Fig. 7 Amplitude ratio of first reflection wave after churning

新油の No.1 は時間が経過してもわずかな振幅の変化しか 見られないが, 使用後の两油 No.2, No.3には大きな振幅の 変化が生じ, 油が劣化するほどその変化速度は急になるこ とが分かる，この振幅の変化は，油中に含まれている污染 粒子の挙動に起因しているものと考えられる.換言すれば, 污染粒子が沈殿する速さの相違は, 油の粘性の差が原因し ているものと考えられる。なお，この結果は短時間で油の 劣化の目安を簡単に得る一つの方法になるのではないかと 考えられる.

Fig. 8 および Fig.9 は, 油温を $40^{\circ} \mathrm{Cおよび} 32^{\circ} \mathrm{C}$ 一定とした 場合の減衰係数亡 NAS 等級との関係を示したものである. 油の種類が異なる何れの場合にも，NAS 等級が大きくなる ほど減衰係数は高い值を示している.特に Fig.8において, 分析結果で得られた同一のNAS 等級の值でも, 超音波で測 


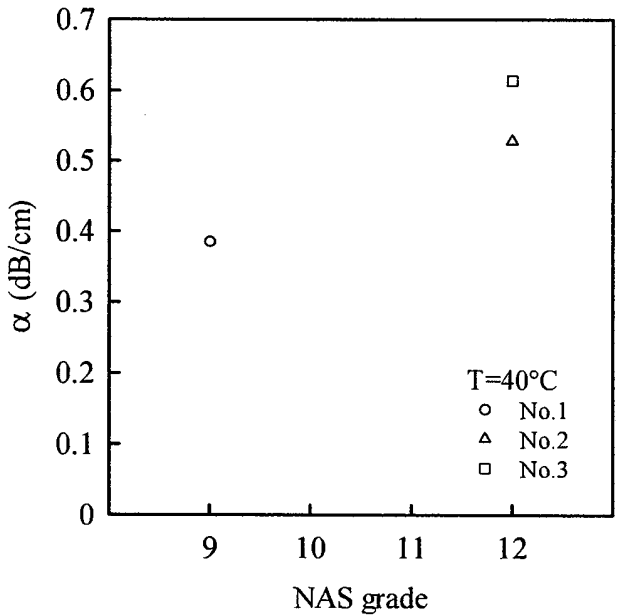

Fig. 8 Relation between NAS grade and damping coefficient of group $\mathrm{A}$
定された減衰係数に差が生じている.すなわち, Table 1 に 示ずように, No.2 と No.3 は同一の NAS 等級であるが，粒 子の総数から算出した体積比はNo.3の方が大きいため, そ の差が出たものと考えられる．従来から油の劣化判定に用 いられているNAS 等級では, Table 2 に示しているように, 同一等級の場合でも各粒子数にある幅を持たせているため, 若干の粒子数に差があっても同じ等級と見なされることに なる。これに対して，本手法による超音波の減衰係数で油 の劣化を評価することは，油中に混入している粒子の総数 や体積比が特定でき, NAS 等級による評価より, より細か な等級分けが可能であることを示唆しているものと考えら れる. 以上の結果より，超音波の減衰係数の值は，油に混 入している污染粒子の総数に起因しているものと考えられ る.

油圧制御システム等の作動油の保守管理を行う場合，例 えば Fig.1 に示したような装置を油圧ニニットに並列に設 置し，タンクの油を本装置を用いて循環させるように工夫 すると, リアルタイムで油の劣化評価が可能になるものと 考えられる。

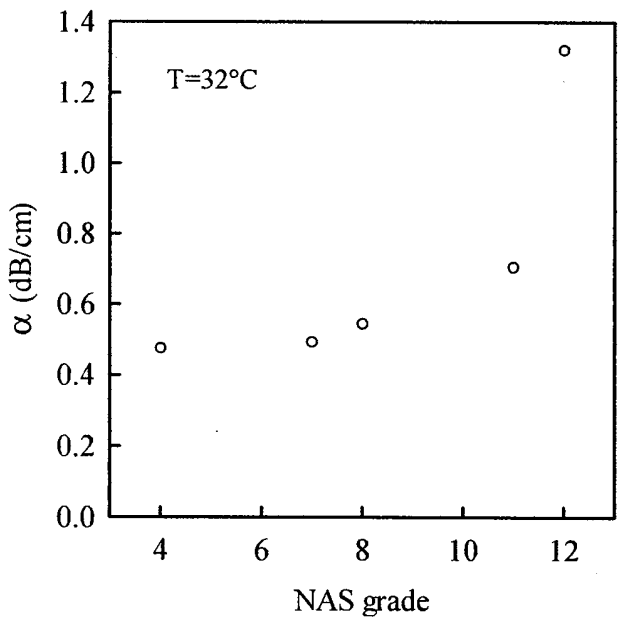

Fig. 9 Relation between NAS grade and damping coefficient of group B

\section{4. 結言}

$5 \mathrm{MHz}$ の超音波探触子を用いて，一探触子法により種々 の油の劣化を評価することを試みた結果，次のような結論 が得られた。

（1）超音波の減衰係数は，油中に混入している污染粒子の 体積比ならびに NAS 等級に良好な相関関係があるこ とが認められた。

(2) これまで一般に用いられてきた NAS 等級よりも，よ り定量的に, かつリアルタイムで油の劣化判定が可能 であることを示した。

\section{5. 参考文献}

（1）超音波便覽編集委員会編, 超音波便覧, (1999), 丸善

(2) 市川, 日比：油圧工学, (2000), 朝倉書店

(3) 根岸, 高木 : 超音波技術, 149(1989), 東京大学出版会

(4) 丹羽：超音波計測，(1982)，昭晃堂 